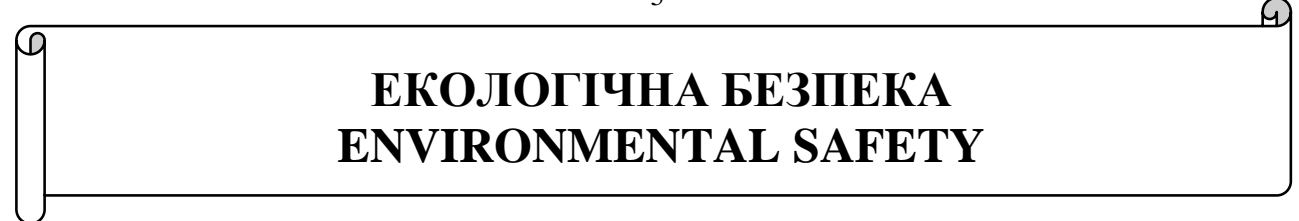

UDC 504.064.2

Tetyana I. Kryvomaz ${ }^{1}$, Dr, professor of Departament of Labour and Environment Protection ORCID ID: 0000-0002-4161-9702 e-mail: ecol@i.ua

Irene Scudu², Chief Technical Advisor

e-mail: irene.scudu@bregroup.com

David Leonard ${ }^{2}$, Head of BREEAM's new construction team

e-mail: david.leonard@bre.co.uk

David Minter ${ }^{3}$, Dr, Leading Researcher

e-mail:d.minter@cabi.org

${ }^{1}$ Kyiv National University of Construction and Architecture, Kyiv, Ukraine

${ }^{2}$ Building Research Establishment Group, London, Great Britain

${ }^{3}$ Centre for Agriculture and Bioscience International, London, Great Britain

\title{
GREEN BUILDING BREEAM IN UKRAINE
}

Abstract. It is recognised that world construction is responsible for substantial amounts of harmful emissions, so the need to save energy and mitigate environmental problems fostered the concept of a green building. This is structures that are sited, designed, built, renovated and operated to energy efficient guidelines, and that they will have a positive environmental, economic and social impact over their life cycle. The study begins with a review of the main stages through which this technology developed in the Great Britain. Notable successes achieved through green building in the UK are then highlighted. There is excellent potential to implement Building Research Establishment Environmental Assessment Method (BREEAM) in Ukraine because, although the building sector is very active, the technology in current use is not up to international environmental standards. At the same time Ukraine is actively subscribing to international conventions which reduce environmental pollution, and seeks to improve national standards in accordance with international requirements. Examples of BREEAM certified green building are already present in Ukraine, and the general economic and political situation seems ready to welcome implementation of green building throughout the country.

Key words: green building; certifications rating system; environmental safety

\section{Introduction}

The building developments have very significant environmental impacts. The building industry is responsible for approximately $40 \%$ of global energy use and $33 \%$ of energy-related greenhouse gas (GHG) emissions [15]. Life Cycle

(c) T.I. Kryvomaz, I. Scudu, D. Leonard, D. Minter, 2019 
Assessments (LCA) of residential buildings and have found that their energy consumption is dominated by the operational phase, which includes all the energy consumed after the construction until the demolition or recycling. Furthermore, the United Nation Energy Programme suggests that $60 \%$ of the energy of the operational phase is used for space heating [2]. Only in UK the built environment accounts for $45 \%$ of total UK carbon emissions, including $27 \%$ from domestic buildings and $18 \%$ from non-domestic [12]. Conversely, it is also the sector with the largest potential to reduce these parameters using currently available technologies. From total $12 \%$ of water use in the world building industry [15], 72\% of domestic emissions arise from space heating and the provision of hot water counted in UK [12]. Total harmful effects to environment made by $40 \%$ of waste [2], wherein $32 \%$ of landfill waste comes from the construction and demolition of buildings, $13 \%$ of products delivered to construction sites are sent directly to landfill without being used [12].

According to a United Nations Environment Programme (UNEP) strategy to build, policymakers should treat resource efficiency as equal in importance to climate policy if they want to move towards a sustainable future [2]. In the next 30 years, 2.4 billion people are likely to move to urban areas, bringing the proportion of the global population living in cities by 2050 to $66 \%$. The annual amount of natural resources used by urban areas could grow from 40 billion tonnes of raw materials in 2010 to 90 billion tonnes by 2050, an increase of $125 \%$, if changes are not made to how cities are built and designed. Historically, existing cities have been spreading at a rate of two per cent a year, increasing global urban land use from just below one million square kilometres to 2.5 million in 2050, and putting agricultural land and food supplies at risk. The increase in urban population will require the building of new cities and the expansion of existing ones. Building and operating these new cities, and supporting the urban lifestyles of those who live in them, requires billions of tonnes of raw materials, such as fossil fuels, sand, gravel, iron ore, wood and food. The report, the 25 th from the International Resource Panel, an eminent group of experts set up by UN Environment in 2007 to examine natural resource use. Unless the world's urban areas make optimal use of their resources, cities will soon demand far more resources than our planet can sustainably provide. As urban areas around the world continue to grow, cities are placing an increasingly heavy burden on our environment, so resource experts call for new strategy to build better cities [13].

The concept of a green building was developed in the 1970s in response to the energy crisis and people's growing concerns about the environment [5]. Green buildings are structures that are sited, designed, built, renovated and operated to energy efficient guidelines, and that they will have a positive environmental, economic and social impact over their life cycle. The need to save energy and mitigate environmental problems fostered a wave of green building innovation that has continued to this day.

\section{Purpose of Research}

The objective of this study is to identify best practice in green building based on the UK's experience, and to promote its application in Ukraine. This involves four tasks:

- reviewing the main stages through which this technology developed in the UK;

- highlighting notable successes achieved through green building in the UK; 
- appreciating the flow of international collaboration between the UK's Building Research Establishment and other countries to promote education in green building and its scientific application;

- understanding the benefits and prospects that can be obtained with implementing green building in Ukraine based on best UK experience.

\section{Result of Research}

In the UK, the harmful impact of the building industry was recognized many years ago. To address the problem, in 1921, the Building Research Establishment (BRE) was set up for making a positive difference in the built environment. BRE is a world leading, multi-disciplinary, building science centre with a mission to improve buildings and infrastructure, through research and knowledge generation. They use cutting edge research to develop a range of products, services, standards and qualifications that are used around the world to bring about positive change in the built environment. Its work played a key role in developing the concept of green building [5].

Four main areas need to be considered in green building: materials, energy, water and health. Materials for green buildings have to be obtained from natural, renewable sources that have been managed and harvested in a sustainable way. Or they are obtained locally to reduce the embedded energy costs of transportation. Or materials salvaged from reclaimed materials at nearby sites. Materials are assessed using green specifications that look at their Life Cycle Analysis (LCA) in terms of their embodied energy, durability, recycled content, waste minimisation, and their ability to be reused or recycled. Passive solar design will dramatically reduce the heating and cooling costs of a building, as will high levels of insulation and energy-efficient windows. Natural daylight design reduces a building's electricity needs, and improves people's health and productivity. Green buildings also incorporate energyefficient lighting, low energy appliances, and renewable energy technologies such as wind turbines and solar panels. Minimising water use is achieved by installing greywater and rainwater catchment systems that recycle water for irrigation or toilet flushing; water-efficient appliances, such as low flow showerheads, self-closing or spray taps; low-flush toilets, or waterless composting toilets. Installing point of use hot water systems and lagging pipes saves on water heating. Using non-toxic materials and products will improve indoor air quality, and reduce the rate of asthma, allergy and sick building syndrome. These materials are emission-free, have low or no VOC content, and are moisture resistant to deter moulds, spores and other microbes. Indoor air quality is also addressed through ventilation systems and materials that control humidity and allow a building to breathe. In addition to addressing the above areas, a green building should provide cost savings to the builder and occupants, and meet the broader needs of the community, by using local labour, providing affordable housing, and ensuring the building is sited appropriately for community needs. Green building requires a holistic approach that considers each component of a building in relation to the context of the whole building whilst considering the impact on the wider environment and community around it. This is a highly complex approach that requires builders, architects and designers to think creatively, using systems integration throughout their work [16].

Life cycle costing (LCC) in accordance with BS ISO 15686 provides a methodology for the systematic economic evaluation of combined capital, operating 
and end-of-life costs of construction project alternatives, to ensure long-term value for project funds. Assessments involve identifying activities during the life cycle, when the activity occurs and associated cost or benefit information for the activity. Life cycle assessment (LCA) in accordance with ISO 14040 defines a methodology for compiling and evaluating the environmental impacts of a product system throughout its life cycle. The standard is not specific to the construction industry, but the principals can be applied for products, building systems and complete buildings, capturing environmental impacts associated with manufacturing, use and disposal [17].

The World Green Building Council report on 'Health, Wellbeing and Productivity in Offices' cites factors such as indoor air quality, thermal comfort and lighting as having a significant financial implication for employers through their impact on staff productivity and absenteeism. The 2013 report by the World Green Building Council making the 'Business case for green building', suggests that certified green buildings have sale prices increased by up to approximately $30 \%$ compared to conventional code-compliant buildings. This is a good perspective for developers. The owner's perspective according to the same report, BREEAM certification can increase rental rates for buildings by up to $24.9 \%$ compared to conventional, code-compliant buildings. The 2014 DLA Piper report suggests that $38 \%$ of the survey participants identified value preservation or increase as the prime benefit of sustainable real estate, followed by reputation (18\%) and reduction of energy costs (15\%). Operating costs: reducing lifecycle costs. 'Staff costs, including salaries and benefits, typically account for about $90 \%$ of a business' operating costs. It follows that the productivity of staff, or anything that impacts their ability to be productive, should be a major concern for any organization [18].

BRE has been owned by the BRE Trust - the largest UK charity dedicated specifically to research and education in the built environment. BRE has been raising the standards of the built environment since 1921, and in the last few years has grown significantly, both through the achievements of people and the acquisition of businesses with beliefs and goals aligned with theirs. Created in 1997 to oversee BRE, the BRE Trust uses profits from the BRE Group to fund new research and education programmes that help meet the main goal of 'building a better world together'. Multi-disciplinary teams include leading experts - working in world-class facilities - in virtually every element of the built environment. They operate internationally, with offices, representatives and partners around the globe, and at Head Office and major facilities in the UK. They generate new knowledge through independent research. This is used to create the products, standards and qualifications that help to ensure buildings, homes and communities are safe, efficient, productive, sustainable and enjoyable places to be. The UK's Building Research Establishment works in 80 countries, and provides more than 16,000 certified products and services [5].

In the past 20 years, BRE Trust has built up strong links with over 50 Universities in the UK with the merging with Construction Excellence. BRE Trust has extended the University Partnerships even further and currently has nearly 100 links. BRE Trust's internationalization strategy focuses on a wide range of activities which encompass joint research, sponsorship for research students, travel grants and awards. The findings of this research have been disseminated in over 3,000 peerreviewed papers, conference proceedings and books, and more than 2,000 students have graduated from BSc and MSc courses supported by the BRE Trust. The level of underpinning fundamental research completed continues to grow, with $128 \mathrm{PhD}$ 
students being funded by the Trust since 2001. This adds to the overall total of more than $300 \mathrm{PhDs}$ now completed or active across the BRE Trust University Partners. More than 35,000 people trained by BRE Academy [5].

The Building Research Establishment's Environmental Assessment Method (BREEAM) sets best practice standards for the environmental performance of buildings through design, specification, construction and operation. Launched in 1990, BREEAM is the world's first and foremost sustainability standard and rating system for the built environment. BREEAM inspires developers and creators to excel, innovate and make effective use of resources. On a global level, over 560,000 BREEAM certificates have been issued and more than two million registered buildings for assessment. Green specifications provide a good set of guidelines for the building industry, but these are still in the process of being formalised into UK regulation and many are open to interpretation. BREEAM has an $80 \%$ market share across Europe for sustainable building certification and they work in 81 countries around the world [4].

The BREEAM AG programme has been designed to teach students about BREEAM, provide them with a professional qualification that will set them apart from their peers and, at the same time, meet the university's curriculum sustainability objectives and complement existing academic programmes, for both undergraduates and postgraduates. BREEAM AG allows universities to connect with the leading industry-used sustainability assessment for both the UK and international markets [4].

BREEAM assessments are carried out by trained assessors based on a scoring system with nine categories: Energy, Land use and ecology, Water, Health and wellbeing, Pollution, Transport, Materials, Waste, Management. Each of the categories is scored and then multiplied by a weighting. There are minimum thresholds that must be achieved, and additions can be made for specific innovative solutions under the category of Innovations. The resulting overall score is translated into one of the BREEAM ratings; unclassified, pass, good, very good, excellent or outstanding. Two stages of assessment and certification are carried out: 1) a design stage assessment resulting in an interim certificate being issued; 2) a post-construction assessment resulting in a final certificate being issued and a rating awarded. It is also possible to carry out a pre-assessment, which can help designers understand aspects of their proposals that need to be improved to achieve the desired rating. For existing building in-use, there is the BREEAM In-Use scheme which allows an action plan to be produced to improve the management and performance both of the building in use and of client activities within the completed building. UK regulations now demand that green specifications are met in all new building design and development, as part of their wider sustainable development strategy, and this means that green buildings are emerging throughout the country [4].

For tenants some of the most important benefits associated with achieving specific BREEAM standards are relatively intangible and difficult to quantify, such as those associated with improved acoustic performance or daylighting. However, an increasing body of evidence points to the relationship between building design, occupant wellbeing and financial outcomes. Whilst BREEAM dominates the UK market, alternative methods of environmental assessment include; Leadership in Energy and Environmental Design (LEED) in the USA, Greenstar in Australia, HQE in France and CASBEE in Japan. The research paper on 'Benchmarking energy use of building environmental assessment schemes' analyses the characteristics of different certification schemes and shows that BREEAM takes into consideration 
operation and performance data; this is a characteristic that differentiates BREEAM from its competitors [11]. Moreover, BREEAM is the only one that addresses management with regards to functionality and controllability of building systems. $43 \%$ of the BSRIA Value of BREEAM survey respondents identified operational cost savings among the benefits of BREEAM. In particular, this report emphasises how BREEAM encourages the use of intelligent controls and smart metering, which can facilitate maintenance and performance and thus reduce associated costs [12]. BREEAM is the world's first and most widely accepted green building certification system.

\section{Discussion}

Resource Requirements of Future Urbanization calls for a new strategy to meet the needs of 21st-century urbanization. The report Sustainable Urban Infrastructure Transitions was produced by UN Environment says that collaborative governance, at all levels, and long-range planning will be needed to transform the cities. Strategies suggested include to achieve a transition to low-carbon, resource-efficient, socially just cities, the report recommends the monitoring the flow of resources entering and leaving the cities to understand the local situation and to help develop resource-efficient strategies.

According to "Development Strategy of the City of Kyiv until 2025", Kyiv planning to have compact growth, to avoid urban sprawl and so economize on the square kilometres of asphalt, the concrete, liveable neighbourhoods where design encourages people to walk or cycle. Better connections by efficient and affordable public transport. The electricity and the water wasted in spread-out cities, so resource-efficient urban components, such as car sharing, electric vehicles and charging point networks, efficient energy, efficient waste and water systems, smart grids, cycle paths, energy-efficient buildings, new heating, cooling and lighting technology, etc [7]. Strategies suggested include infrastructure for cross-sector efficiency, such as using waste heat from industry in district energy systems and industrial waste materials in construction, such as fly-ash bricks. It examines establishing a new model for city governance and politics that supports imaginative business propositions and experimentation [13]. According to the main objective of the Strategy, long-term development of the city of Kiev perfectly correlates with the basic principles of green construction [7, 13].

The collaborative governance, at all levels, and long-range planning will be needed to transform the region's cities of all Ukraine. Undertaking national urbanization planning to balance economic growth across a range of city sizes. Promoting compact, mixed-use, accessible and inclusive cities through regional and city planning to reduce land-use planning, streamline infrastructure provisions and promote sustainable mobility. Promoting resource efficiency at the systems level across the city through innovative and profitable exchanges of "waste" energy and materials. Developing cities through land-use planning that rehabilitating existing buildings in resource-efficient buildings, promoting resource-efficient, resilient buildings and electricity grids [13].

Corporate image and compliance with CSR requirements Developer, Owner, and Tenant: The Innovate UK Technology Strategy Board report, suggests that BREEAM gives clients 'a way to differentiate themselves in a competitive market with a highly visible, authoritative and internationally recognised quality mark'. 
More specifically, the survey conducted by BSRIA on the Value of BREEAM, suggests that, from a 'social perspective', industry recognition is the most significant benefit, followed by advantages in public relations and Corporate Social Responsibility (CSR). In fact, approximately $40 \%$ of the developers surveyed considered CSR one of the main reasons to pursue a BREEAM certification.

Project owners and planners need to understand how communication influences green implementation. Green planning is critically important during the design phases of construction projects but continually gets less attention during construction. Successful implementation of sustainability goals not only provides economic benefits from fully exploiting life-cycle costs, but also holds the promise of providing a healthier working environment [10].

Ukraine is actively subscribing to international conventions which reduce environmental pollution, and seeks to improve national standards in accordance with international requirements. Objective of the reform initiative is to increase institutional capacities of market surveillance system with advanced tools, new methodologies, and creation of a product safety ecosystem by engaging other stakeholders - business and consumers in making the market clean, safe, and complied with the international standards. There are already examples of BREEAM certificed green building in Ukraine. The business center Astarta in Kyiv and Optima Plaza business park in Lviv had compliance with the requirements of the certification system BREEAM. In June 2017 works for the complex "Park Lake City" near Kyiv started, which include residential buildings, shopping center, kindergarten and elementary school. There are also some others green building projects designed according to BREEAM requirements, but they haven't been widely announced yet. Although the analysis results show that early and continuous communication of sustainability design goals with field supervision personnel has a significant impact on whether those goals are realized [10]. The findings of this study support the growing importance of green building as a component of the whole construction market and provide a benchmark against which to measure future changes in the industry over time [6].

In an age threatened by climate change, energy shortages and ever-increasing health problems it makes sense to build homes that are durable, save energy, reduce waste and pollution, and promote health and wellbeing. A green building is more than a model for sustainable living; it can build hope for the future. Although in Ukraine its very new and power known direction, green building is a very perspective and a rapidly growing field. There is excellent potential to implement BREEAM in Ukraine because, although the building sector is very active, the technology in current use is not up to international environmental standards. The general economic and political situation in Ukraine seems ready to welcome implementation of green building throughout the country. Green building is an essential component of sustainable development and should especially pay attention to group into five themes: green building management in general, the benefits and barriers to green building development, green building performance, stakeholder behavior with regard to green buildings, and green building strategies. Future directions for research relating to green building are suggested for the areas stakeholder management, policies and incentives, communication platform development, and retrofitting of existing buildings [9].

Green building development will be an important area in Ukraine, and more comprehensive studies on green building can help to promote further progress in this 
field. Therefore the Center for Green Building Development was created in Kiev National University of Construction and Architecture on a base of Innovative Education Institute. The program of this Center is structured to provide the progressive sustainability building design to construction and operations industry. It will improve in collaboration with state agencies and industry stakeholders and could serve as a model for localized green building programs. The benefits of green buildings can be grouped within three categories: environmental, economic and social.

One of the most important types of benefit green buildings offer is to our climate and the natural environment. Green buildings can not only reduce or eliminate negative impacts on the environment, by using less water, energy or natural resources, but in many cases they can have a positive impact on the environment by generating their own energy or increasing biodiversity. The building sector has the largest potential for significantly reducing greenhouse gas emissions compared to other major emitting sectors [15]. The building sector has the potential to make energy savings of $50 \%$ or more in 2050 , in support of limiting global temperature rises to $2^{\circ} \mathrm{C}$ above pre-industrial levels [2]. Global energy efficiency measures could save an estimated $€ 280$ to $€ 410$ billion in savings on energy spending [14].

Green buildings offer a number of economic or financial benefits, which are relevant to a range of different people or groups of people. These include cost savings on utility bills for tenants or households through energy and water efficiency; lower construction costs and higher property value for building developers; increased occupancy rates or operating costs for building owners; and job creation [17]. Building owners report that green buildings - whether new or renovated - command a $7 \%$ increase in asset value over traditional buildings [16]. Green building benefits go beyond economics and the environment, and have been shown to bring positive social impacts too. Many of these benefits are around the health and wellbeing of people who work in green offices or live in green homes. Workers in green, wellventilated offices record a 101\% increase in cognitive scores and brain function [8]. Employees in offices with windows slept an average of 46 minutes more per night [1]. Research suggests that better indoor air quality, such as low concentrations of $\mathrm{CO}_{2}$ and pollutants, and high ventilation rates, can lead to improvements in performance of up to $8 \%$ [3].

The world over, evidence is growing that green buildings bring multiple benefits. They provide some of the most effective means to achieving a range of global goals, such as addressing climate change, creating sustainable and thriving communities, and driving economic growth.

\section{Conclusion}

The construction industry has a huge negative impact on the environment. Green building offers a way to reduce that at all stages of the industry's cycle from site preparation, through selection and preparation of source materials, transport, construction, and use, to renovation and eventual demolition. In short, green building is the best and most advanced technology available if construction is to become sustainable. Green building is an essential component of sustainable development, but previous studies have offered little in the perspective of green building development in Ukraine. This research presents the current trends in this topic.

In the UK, the harmful impact of the building industry was recognized many years ago. To address the problem, in 1921, the Building Research Establishment was set 
up. Its work played a key role in developing the concept of green building. It also established BREEAM, the world's first and most widely accepted green building certification system. The UK's Building Research Establishment works in 80 countries, and provides more than 16,000 certified products and services. More than 35,000 people have been trained through its Academy. Notable recent achievements of the Establishment include over 560,000 buildings with certified BREEAM assessment ratings, and more than two million registered for assessment. BREEAM has an $80 \%$ market share across Europe for sustainable building certification. The UK's Building Research Establishment collaborates internationally in the fields of education and science to conduct research which generates the knowledge, skills and tools needed to create a better built environment for all. The findings of this research have been disseminated in over 3,000 peer-reviewed papers, conference proceedings and books, and more than 2,000 students have graduated from BSc and MSc courses supported by the Building Research Establishment Trust.

The percentage of firms expecting to have more than $60 \%$ of their projects certified green is anticipated to more than double from $18 \%$ currently to $37 \%$ by 2020 , which recognition by owners of the benefits of green is critical to sustaining green market growth globally. The anticipated growth is largely driven by countries that still are developing green markets such as Ukraine. Green building is an essential component of sustainable development and should especially pay attention to group into five themes: green building management in general, the benefits and barriers to green building development, green building performance, stakeholder behavior with regard to green buildings, and green building strategies. Future directions for research relating to green building are suggested for the areas stakeholder management, policies and incentives, communication platform development, and retrofitting of existing buildings.

There is excellent potential to implement BREEAM in Ukraine because, although the building sector is very active, the technology in current use is not up to international environmental standards. Ukraine is actively subscribing to international conventions which reduce environmental pollution, and seeks to improve national standards in accordance with international requirements. There are already examples of BREEAM certificated green building in Ukraine, and the general economic and political situation seems ready to welcome implementation of green building throughout the country. Green building development will be an important area in Ukraine, and more comprehensive studies on green building can help to promote further progress in this field.

\section{REFERENCES}

1. Abdul, Y., and Quartermaine, R. (2014). Delivering sustainable buildings: savings and payback. London: BRE, Sweett Group. IHS BRE Press.

2. Baynes, T., Bergesen, J., Labbé, F., Musango, J.K., Ramaswami, A., Robinson, B., Salat, S., Suh, S., Currie, P., Fang, A., Hanson, A., Kruit, K., Reiner, M., Smit, S., Tabory, S. A Report by the International Resource Panel. United Nations Environment Programme, Nairobi, Kenya. The Weight of Cities summary report (2018). Available online: http://www.resourcepanel.org/reports/weight-cities.

3. Bienert, S. (2014). Extreme weather events and property values: Assessing new investment frameworks for the decades ahead. London: Urban Land Institute.

4. Building Research Establishment Environmental Assessment Method. Available online: https://www.breeam.com/ 
5. Building Research Establishment Trust. Available online: https://bregroup.com/bretrust.

6. De Luca, P., Carbon, I., and Nagy, J. B. (2017). Green building materials: a review of state of the art studies of innovative materials. Journal of Green Building. 12 (4): 141-161.

7. Development Strategy of the City of Kyiv until 2025 [Стратегія розвитку міста Києва до 2025 року затверджено рішенням Київської міської ради №824/7060 від 15 грудня 2011 р., нова редакція 2016 р.]

8. Fekry, A. A., El Zafarany, A. M, Shamseldin, A. K. M. (2014). Develop an environmental assessment technique for human comfort requirements in buildings. HBRC Journal. 10(1): $1-9$.

9. Huo, X. and Yu, A. T.W. (2017). Analytical review of green building development studies. Journal of Green Building. 12(2): 130-148.

10. Kim, J.J., Goodwin, C.W., and Kim, S. (2017). Communication turns green construction planning into reality. 12 (1): 168-186.

11. Lee, W. L. (2012). Benchmarking energy use of building environmental assessment schemes. Energy and Buildings. 45: 326-334.

12. Soulti, E., and Leonard, D. (2016). The value of BREEAM A review of latest thinking in the commercial building sector. London: BRE Global Ltd.

13. The Weight of Cities: Resource Requirements of Future Urbanization. Swilling, M., Hajer, M. (2018). International Resource Panel. Available online: http://www.resourcepanel.org.

14. Thompson, M., Cooper, I., Gething, B. (2015). The business case for adapting buildings to climate change: Niche or mainstream? Innovate UK Technology Strategy Board.

15. United Nations Environment Programme 2009 Annual Report (2009). 94 p. Available online: http://www.unep.org/10yfp/programmes/sustainable-buildings-and-constructionprogramme.

16. World Green Building Trends 2016 report. Available online: https://www.construction.com/toolkit/reports/world-greenbuilding

17. World Green Building Trends 2018 SmartMarket Report. Available online: https://www.worldgbc.org/news-media/world-green-building-trends-2018-smartmarketreport-publication

18. World Green Building. Available online: http://www.worldgbc.org

The article was received 10.01.2019 and was accepted after revision 30.01.2019

\section{T.I. Кривомаз, А. Скуду, Д. Ленед, Д. Мінтер ЗЕЛЕНЕ БУДІВНИЦТВО ВRЕЕАМ В УКРАЇНІ}

Анотація. Загальновизнано, що будівельна галузь відповідає за значні обсяги шкідливих викидів, тому потреба в економії енергії та необхідність вирішення проблем довкілля сприяли розвитку концепції зеленого будівництва. Це будівництво та експлуатація енергоефективних споруд з підвищеним комфортом та мінімальним впливом на навколишне середовище протягом всього життєвого циклу з урахуванням економічних та соціальних аспектів. Розглянуто основні етапи розвитку цієї технології у Великобританії та відмічено значні успіхи, досягнуті завдяки зеленому будівництву. В Україні існує чудовий потенціал для впровадження методу екологічної оцінки будівельних проектів (BREEAM), оскільки, незважаючи на значну активність будівельного сектору, технології, що використовуються в даний час, не відповідають міжнародним екологічним стандартам. Водночас Україна бере активну участь у міжнародних конвенціях, спрямованих на зменшення забруднення навколишнього середовища, у зв'язку з чим проводиться адаптація національних стандартів у відповідності до міжнародних вимог. В Україні вже сертифіковано ряд діючих проектів та будівель за стандартами зеленого будівництва BREEAM, а загальна економічна і політична ситуація сприяє розвитку та впровадженню зеленого будівництва по всій країні.

Ключові слова: зелене будівництво; сертифікаційна рейтингова система; екологічна безпека 


\section{Кривомаз Тетяна Іванівна}

доктор технічних наук, кандидат біологічних наук, професор кафедри охорони праці та навколишнього середовища Київського національного університету будівництва та архітектури

Адреса робоча: 03037 Україна, м. Київ, проспект Повітрофлотський, 31

e-mail:ecol@i.ua

ORCID ID: 0000-0002-4161-9702

\section{Айрін Скуду}

головний технічний консультант BREEAM Науково-дослідного центру будівництва Адреса робоча: Велика Британія, Лондон, Хартфордшир, Ватфорд, BRE Group e-mail: irene.scudu@bregroup.com

\section{Девід Ленед}

керівник команди нового будівництва BREEAM Науково-дослідного центру будівництва

Адреса робоча: Велика Британія, Лондон, Хартфордшир, Ватфорд, BRE Group e-mail: david.leonard@bre.co.uk

\section{Девід Мінтер}

доктор, провідний науковий співробітник Міжнародного центру сільського господарства та біологічних наук

Адреса робоча: Велика Британія, Лондон, Уоллінгфорд, САВI

e-mail:d.minter@cabi.org 